\title{
EXPERIENCES IN ACQUIRING TITLES AMONG LAND CLAIMANTS IN LAMP MUNICIPALITIES IN LEYTE 1 !
}

\author{
Rotacio S. Gravoso, ERNESTo F. Bulayog, and \\ Ma. ANABELle D. Gerona \\ Visayas State University, Visca, Baybay, Leyte
}

\section{ABSTRACT}

This paper presents land claimants' experiences in acquiring land titles under the sporadic and LAMP land titling schemes. Data were gathered using an interview schedule. Respondents were land claimants from the pilot areas of LAMP-PIO I. Most of them were old, married, obtained high school education, and had annual income that fell below the poverty line. Findings showed that under the LAMP scheme, claimants were able to get their title within about a year. On the other hand, it took an average of 7 years for land claimants to get their title in the sporadic scheme. Respondents who claimed that the LAMP scheme is more effective said that it is faster, cheaper and most importantly, has more systematic procedures.

KEY WORDS: Cost of land titling, land administration and management, farmers, Leyte

11 This paper is part of the research funded by the Australian Govemment through the Phillippines-Australian Land Administration and Management Project (LAMP) 


\section{INTRODUCTION}

One of the pressing problems in the Philippines is "an inefficient and ineffective land administration system that constrains economic development, reduces opportunities for the poor, and discourages sustainable management of resources" (see LAMP website http:/www.phil-lamp.org/index.htm). In response to this problem, the Land Administration ard Management Program (LAMP) was established.

As an inter-agency project of the government of the Philippines, LAMP started its implementation in January 2001. Its aim is to establish a comprehensive, complete, secure, community accepted, and sustainable land administration system that integrates the operations of several agencies in a discrete area supported by simplified and streamlined procedures. In Eastern Visayas, LAMP is being piloted in the municipalities of Alang-alang, Dagami, Palo, Pastrana, San Miguel, and Sta. Fe in the province of Leyte. The pilot implementation ended in December 2004. However, land titling activities are expected to continue within 20 years not only in the pilot sites but also in other areas of the country.

The ultimate goal of the pilot implementation of LAMP is to fast track land titling. Thus, new procedures, otherwise known as systematic approach, for land titling have been established. Under this new system; various modalities for land titling can also be availed of. These include judicial titling, homestead patent, miscellaneous sales patent, free patent, agricultural lease and agricultural sales patent (LAMP-Leyte, n.d.).

Classified into mass and voluntary application, the judicial title are applicable for agricultural and residential lands. In mass judicial application, the petition is filed by the government represented by the DENR Regional Executive Director, while in voluntary application, the petition is filed by the owner. Intended for agricultural lands, the agricultural sales patent allows married women to apply, and more than one owner can be listed on the title. 
Homestead patent is cheaper than agricultural sales patent. Under this scheme, lots without an approved survey may be applied for. In agricultural lease, the allowable area for individual application for agricultural lands is $500 \mathrm{ha}$. and $1000 \mathrm{ha}$. for corporations/associations. The property can be leased for 25 years and may be renewed for another 25 years. Miscellaneous sales patent for residential lands has no restriction on women applicants, no restriction on sales or mortgage and no "head of the family" requirement. However, evidence of 30 years continuous, open and notorious occupation is required. In free patent, women and minors can apply for a maximum of 12 hectares of land for a title.

Each of the abovementioned schemes in land titling employs different requirements, and differs in processing time and activities. Although there is a one-stop-shop service in land titling being offered by LAMP PIO I, costs of land titling may have differed between schemes and across modalities. Meanwhile, some residents in LAMP municipalities continue to avail of the sporadic scheme of land titling. So, for the land claimants, which is more convenient and beneficial to them, the non-LAMP or the LAMP scheme? To answer this question, this study was conducted. Results of this study can be used in coming up with a package of appropriate recommendations to the land claimants in terms of titling their lands. Results could also contribute to the policy advocacy efforts of LAMP.

\section{METHODOLOGY}

\section{Study Sites}

Data were gathered in the following pilot sites of LAMP in Leyte: Palo, Alang-Alang, San Miguet, and Dagami. The choice of these areas was based on the following: 1) Based on data from LAMP, land tilting activities have already started in these areas, and 2) Some residerits of these areas have already acquired land titles through the sporadic tilling scheme, thus ensuring the possibility of comparing the costs by clients. 


\section{Respondents}

As discussed earlier, this study aimed to compare costs incurred by the claimant when applying for land titles. Thus, it was necessary that respondents be representatives of all methods of land titling offered not only by LAMP but also by other land titling agencies. In this study, the initial plan was to interview a random sample of land titleholders in the study sites. As it turned out in the field, however, interviewing the randomly sampled titleholders was not feasible, as those in the list have already died many years ago. As an alternative, the second or third claimants were interviewed. The problem, however, was that these heirs did not know much about the costs involved. As a last option, the titleholders given by the barangay captains were interviewed. From these approaches, 100 respondents were interviewed. The distribution of respondents in terms of their place of origin is presented in Table 1.

Table 1. Distribution of respondents in terms of places of origin

\begin{tabular}{lcccc}
\hline Municipality & LAMP & Sporadic & $\begin{array}{c}\text { Both Sporadic } \\
\text { and LAMP } \\
\text { Schemes }\end{array}$ & $\begin{array}{c}\text { Not } \\
\text { Specified }\end{array}$ \\
\hline Palo & 16 & 9 & 7 & 2 \\
Alang-alang & 0 & 7 & 0 & 0 \\
San Miguel & 1 & 34 & 3 & 0 \\
Dagami & 21 & 0 & 0 & 0 \\
Total & -38 & -50 & -10 & -2 \\
\hline
\end{tabular}

Some respondents had more than one titles. One title was obtained through the sporadic means, while the other was obtained through LAMP scheme

\section{Data Gathering and Analysis}

To gather the data, an interview schedule was used. The interview schedule was composed of three parts. In-depth interviews were also conducted to gather additional information regarding respondents' experiences in acquiring land titles. 
Prior to data gathering, the interview schedule was pretested with 10 land claimants whose characteristics matched the target respondents. The objective of this pretest was to determine the comprehensibility of the questions. Results of the pretest were used in modifying the questions and estimating the length of the interview.

Descriptive statistics were used to describe the respondents and their feedback on the two land titling schemes. Information from the indepth interviews were presented in narrative format.

\section{RESULTS AND DISCUSSION}

\section{Respondents' socio-demographic profile}

Table 2 presents respondents' socio-demographic characteristics. Ages of the respondents were categorized based on the age classification by the National Economic Development Authority - that is, those who were below 21 years old were young; 22 to 45 years old, middle aged; and those within the range of 46 to 65 , old. Of the 98 respondents who reported their age, a big proportion belonged to the old category $(93.9 \%)$. Only a few were in the middle-aged bracket $(6.1 \%)$. Interestingly, no respondent fell into the young age category. As regards sex, more than half $(56 \%)$ of the respondents were male and the rest $(44 \%)$ were female. Furthermore, a big proportion of them $(87.2 \%)$ were married. The rest were either widow/widowers $(11.7 \%)$. A lone respondent was still single.

Table 2. Respondents' socio-demographic characteristics

\begin{tabular}{|c|c|c|}
\hline Variable & $\begin{array}{c}\text { Frequency } \\
(\mathrm{n}=100)\end{array}$ & $\begin{array}{l}\text { Percent } \\
(\%)\end{array}$ \\
\hline $\begin{array}{l}\text { Age } \\
\text { Middle aged ( } 22-45 \text { years old) } \\
\text { Old ( } 46-65 \text { years old) } \\
\text { No answer }\end{array}$ & $\begin{array}{c}6 \\
92 \\
\frac{2}{100}\end{array}$ & $\begin{array}{r}6.00 \\
92.00 \\
2.00 \\
100.00\end{array}$ \\
\hline $\begin{array}{l}\text { Sex } \\
\text { Male } \\
\text { Female }\end{array}$ & $\begin{array}{l}56 \\
44 \\
100\end{array}$ & $\begin{array}{r}56.00 \\
44.00 \\
100.00 \\
\end{array}$ \\
\hline
\end{tabular}


Table 2. (cont'd.)

\begin{tabular}{|c|c|c|}
\hline Variable & $\begin{array}{c}\text { Frequency } \\
(n=100)\end{array}$ & $\begin{array}{c}\text { Percent } \\
(\%)\end{array}$ \\
\hline \multicolumn{3}{|l|}{ Civil Status } \\
\hline Single & 1 & 1.00 \\
\hline Married & 82 & 82.00 \\
\hline Widow/Widower & 11 & 11.00 \\
\hline No answer & 6 & $\therefore 6.00$ \\
\hline Total & 100 & 100.00 \\
\hline \multicolumn{3}{|l|}{ Educational Attainment } \\
\hline Elementiry & 23 & 23.00 \\
\hline Secrindary & 28 & 28.00 \\
\hline College & 42 & 42.00 \\
\hline Postgraduate (masters \& doctoral) & 3 & 3.00 \\
\hline No answer & 4 & 4.00 \\
\hline Total & 100 & 100.00 \\
\hline \multicolumn{3}{|l|}{ Level of income } \\
\hline $\begin{array}{l}\text { Below poverty line } \\
\text { (below } 254,340.00 / \text { annum) } \\
\text { Above the poverty line }\end{array}$ & 47 & 47.00 \\
\hline (above $P 54,340.00$ /annum) & 33 & 33.00 \\
\hline Don't know & 20 & 20.00 \\
\hline Total & 100 & 100.00 \\
\hline
\end{tabular}

It is worth noting more that two-fifths $(43.75 \%)$ of the respondents had college education. Likewise, a bigger number of respondents received high school education $(29.16 \%)$ than those who received elementary education $(23.97 \%)$.

The respondents obtained their income from different sources. For on-farm solirces, almost three-fourths $(69.23 \%)$ reported that they have coconut farms, while close to one-third $(30.77 \%)$ had rice farms. Almost one-fourth $(24.6 \%)$ had sari-sari stores. Other off-farm income sources included pensions, salaries, huiorarium, and wages. A few were receiving remittances from Manila and abroad. Based on the classification by the National Statistics Coordinating Board in Region 8, more than half $(58.75 \%)$ of the 80 respondents who reported their income fell below the poverty line (below 254 , 340/annum). 
Interestingly, more than a third had incomes above the poverty line $(\because 54$, 340.00/annum).

\section{Feedback on the Land Titling Services}

Respondents were asked to give their comments on the land titling services provided to them. They were first asked to describe the services they thought are ideal to be given to land claimants and if this quality of service has been provided to them. Results are presented in Table 3.

For the qualities of their ideal land sitling services, easy and quick process topped the list among the three groups. When probed if their ideal service quality has been provided, a greater number of respondents who avaled of the LAMP (44.12\% vs. $55.88 \%$ ) and sporadic schemes ( $50 \%$ for both) answered in the negative than in affirmative.

Table 3. Respondents' feedback on the quality of land titling services provided ${ }^{*}$

\begin{tabular}{|c|c|c|c|c|c|c|}
\hline \multirow{3}{*}{ Qualities of ideal fand titling services } & \multicolumn{6}{|c|}{ Land Titling Schemes Availed } \\
\hline & \multicolumn{2}{|c|}{$\begin{array}{l}\text { LAMP } \\
(n=35)\end{array}$} & \multicolumn{2}{|c|}{$\begin{array}{c}\text { Sporadic } \\
(n=50)\end{array}$} & \multicolumn{2}{|c|}{$\begin{array}{c}\text { Both Schemes } \\
(n=12)\end{array}$} \\
\hline & $n$ & $\%$ & $\mathrm{~N}$ & $\%$ & $n$ & $\%$ \\
\hline Easy and quick process & 30 & 85.72 & 37 & 74.00 & 7 & 58.33 \\
\hline Smiling and cheerfol & 2 & 5.71 & 0 & 0.00 & 2 & 16.67 \\
\hline Shows sincerity to clients & 0 & 0.00 & 2 & 4.00 & 0 & 0.00 \\
\hline Low cost & 0 & 0.00 & 0 & 0.00 & 1 & 8.33 \\
\hline Good information dissemination & - & - & - & - & * & - \\
\hline No answer & 3 & 8.57 & 11 & 22.00 & 2 & 16.67 \\
\hline Fulfillment of the quality service & 35 & 100.00 & 50 & 100,00 & 12 & 100.00 \\
\hline Fuffilled & 15 & 42.86 & 22 & 44.00 & 7 & 58.33 \\
\hline Not fulfïlled & 19 & 54.29 & 22 & 44.00 & 4 & 33.33 \\
\hline No answer & 1 & 2.86 & 6 & 12.00 & 1 & 8.34 \\
\hline Qualities of services actually given & & & & & & \\
\hline Slow & 17 & 48.57 & 19 & 38.00 & 2 & 16.67 \\
\hline Procedures difficult to follow & 1 & 2.86 & 1 & 2.00 & 0 & 0.00 \\
\hline Information not widely disseminaled & 0 & 0.00 & 0 & 0.00 & 1 & 8.33 \\
\hline No answer & $\begin{array}{l}17 \\
35\end{array}$ & $\begin{array}{l}48.57 \\
100.00\end{array}$ & $\begin{array}{l}30 \\
50\end{array}$ & $\begin{array}{l}60.00 \\
100.00\end{array}$ & $\begin{array}{l}9 \\
12\end{array}$ & $\begin{array}{l}75.00 \\
100.00\end{array}$ \\
\hline
\end{tabular}


As could be gleaned from the data; 11 respondents have availed of the LAMP and sporadic schemes. They were then asked for the scheme they thought was more effective. Since one of the respondents said that both were effective, responses were equally divided. Reasons for choosing sporadic included: fast and cheap. Interestingly, some respondents felt that LAMP and sporadic schemes are just the same. A lone respondent even said that the sporadic scheme is even better than the LAMP scheme. These comments are misperceptions because following the procedures at the LAMP.PIO 1, the average length of time before a claimant could get a title varied significantly: 1 year for LAMP and 7 years for sporadic.

On the other hand, those who claimed that the LAMP scheme is more effective said that the LAMP staff are professional, fast, and that LAMP uses systematic procedures. The last comment is understandable because LAMP has established a system for acquiring land titling. Some respondents even stressed that with LAMP, land titling has become more convenient. An example they have given was the fact that LAMP has established base camps. These base camps, according to them, relieves them of the burden of going to Tacloban to follow up their application.

Respondents were also asked for their suggestions to improve land titling services (Table 4). Interestingly, for respondents who have availed of the sporadic scheme, the dominant suggestion was "to process land titles even without under the table transactions" (43.48\%). Another thing that is worth noting is the suggestion to clarify requirements for land titling. This underscores the fact that in sporadic scheme, land titling causes a lot of confusion.

Respondents who have availed of the LAMP services (25\%) also suggested the elimination of "under the table negotiations". Although they observed that the establishment of $\triangle A M P$ has reduced this problem significantly, they still have fallen victims especially in the office where they finally obtain their titles. 
Table 4. Respondents' suggestions to improve land titling services

\begin{tabular}{lcccc}
\hline Suggestions & \multicolumn{2}{c}{ LAMP } & \multicolumn{2}{c}{ Sporadic } \\
\cline { 2 - 5 } & $\mathrm{N}=12$ & $\begin{array}{c}\text { Percentag } \\
\mathrm{e}\end{array}$ & $\mathrm{N}=23$ & $\begin{array}{c}\text { Percentag } \\
\mathrm{e}\end{array}$ \\
\hline $\begin{array}{l}\text { Process land titles even without } \\
\text { "under the table" transaction }\end{array}$ & 3 & 25.00 & 10 & 43.48 \\
Fast track land titling & 4 & 33.33 & 5 & 21.74 \\
Staff should work together & 2 & 16.67 & 4 & 17.39 \\
Lower cost & 1 & 8.33 & 3 & 13.00 \\
Clarity requirements & 0 & - & 1 & 4.80 \\
Implement land titling activities in & 2 & 16.67 & 0 & - \\
$\quad$ other areas & & & & \\
\multicolumn{1}{c}{ Total } & 12 & 100.00 & 23 & 100.00 \\
\hline
\end{tabular}

Two respondents who have availed of the LAMP scheme have suggested to expand the land titling services to other areas. This suggests that titling services under LAMP is already satisfactory that people feel that its benefits should also be enjoyed by other land claimants.

\section{Illustrative Cases}

Complimenting the findings of the survey are data gathered through in-depth interviews presented as illustrative cases.

Acquiring a free patent through the sporadic scheme. Aleck Lawson is a 68-year old farmer who is engaged in planting banana and coconut. He has not gone to school, but he can read and write as his mother had taught him the skills.

At this time, Aleck is managing a total of 30 ha. of land. However, 20 ha. have just been mortgaged to him (prenda in the Philippines). He uses these lands for his banana and coconut plantations. 
Aleck obtained two free patents for his two lots (totaling $10 \mathrm{ha}$.) he bought in the 70s. His first attempts to get the titles were unsuccessful. He recalled that a certain Tito who was working with DENR promised him to process the titles for him. He gave him R5,000. Today, he only knows that Tito had already retired from service and is now in Ormoc.

Through a staff working at the DENR who is actually a friend of his neighbor, Aleck again applied for the land titles in 1996. He then gave all his documents and the amount of $\mathrm{R7}, 000$ to this DENR staff. In two months, he got the title. He could not recall, however, what the R7, 000 were spent for neither does he want to think that he spent R5, 000 earlier for nothing. "What matters to me now is that, I got the title I so desire," he said.

Acquiring a free patent via LAMP. Eddie Ross, a captain in their barangay, is among the heirs of the pieces of land their grandfather and mother left them. Coming in three parcels, these lots are in his barangay in San Miguel, Leyte. Under LAMP, these lots are now known as Lot 703, a 0.4-ha. area registered in the name of their mother, and Lots 4892 and 3171 (2.1-ha. and 0.6-ha. areas) registered with their grandfather. During the conduct of this study, Eddie has already received the titles for Lot 703 and Lot 4892. In fact, the title for Lot 703 has been issued on July 11,2003 yet, while that of Lot 4892, on September 9, 2004. He said that he started filing the applications in March 2003, when LAMP staff started their campaign on land titling in their barangay.

How did Eddie get the titles? He related that sometime in March 2003, staff from LAMP came to their barangay and sat in their council meeting. In this meeting, the LAMP staff discussed the land titling activities being undertaken by LAMP. Convinced of the benefits of the project, the council passed a resolution allowing LAMP to implement land titling activities in their barangay. To properly inform the barangay residents, a general assembly was organized. In this assembly, LAMP staff discussed the processes involved in land titling and the corresponding fees. 
Eddie considers getting the land title via the LAMP scheme as easy and cheap. He said residents in his barangay like him did not anymore need to go to Tacloban City to follow-up their papers as the LAMP staff were stationed in their barangay hall on a designated day. When they had questions, the residents just went to their barangay hall.

Based on official receipts, Eddie has only paid a total of R2, 262.28 for the three titles. He paid this amount to the CENRO. These expenses included cadastral cost (₹660), interest (2752.40), application (F150), and registration and issuance of titles (⒍89.88). Eddie said that he paid P40 for the documentary stamps of the three titles. For transportation expenses, he reported that so far, he only spent a total of $P 90.00$ to get the two tittes: $R 50$ when he got the title for Lot 703 at the LAMP office in Palo and 240 when he acquired the title for Lot 4892 . He further said that for the latter, the title was obtained at the LAMP's Base Camp in San Miguel Poblacion. In both cases, he was informed to pick up the papers when they were already ready. So, he did not anymore have to come back to the office.

Although one title is still being processed (for Lot 3171), Eddie is generally happy with the services and assistance provided by LAMP. He said that with LAMP, land tilling did not only come cheap but also fast. He recalled that in the $70 \mathrm{~s}$, when his mother was still alive, she actually exerted efforts to have her lands titled. An agent then kept on coming with a promise to get the lands titled. Every visit then meant money. If taken at the current value, the money his mother has given to the agent may total to $\mathrm{P} 20,000$. However, she never got a title until she died.

What he wants to improve in LAMP is updating of the status of their application. For example, according to him, until now he does not know yet why the title for Lot 3171 he applied for has not been released. He related, however, that when the LAMP-PIO Manager visited them lately, he brought this query to him and the manager took note of this problem. 
Getting a judicial title the sporadic way. Peter Mills is a 73-year old resident in Palo, Leyte. He got a judicial tifle for his 500 square meter residential lot in 1995. However, he filed his application in 1991 yet. According to him, he first went to the Registry of Deeds to obtain information on titing activities and requirements. He filled out the forms and submitted the same to the ROD. He could not recall how much he spent in these steps. However, he said that one day, he was called to go to the Bureau of Lands and paid R500 for some pertinent documents. After about four years, Peter got his title. "That's after coming to the ROD for 10 times," he said. At that time, according to him, the fare was 1.50 yet from his barangay to the offices in Tacloban. He confided that to get the title at the ROD, he gave $\$ 10,000$.

Peter expressed dissatisfaction on the services given to him. "It took too long before I could get the title". He is so grateful though that he, at last, obtained the title. To improve the services, he is suggesting that the staff and offices taking charge of land titling should work together to facilitate work. "What I disliked most was that, the offices seemed to be working on their own. The process was too tiring and confusing," he pointed out:

Getting a judicial title through LAMP. Terry Jacob is a Ph. D. degree holder and has taught college in a government school. In fact, on her retirement, she was the officer-in-charge of her school.

Terry applied for the title where their residential house stands in 2003 when LAMP started the campaign on judicial titling in their place. To date, however, she has not yet received the title.

Terry describes the LAMP system as confusing. She related that one time, all land claimants covered by LAMP in their municipality were asked to report to their municipal office for an interview. The gathering, she said, tumed out be chaotic. "There were no'specific instructions given to us." This is not to mention, according to her, everyone's fear that the building would fall as the municipal building is old. 
Aside from her observations that LAMP is unsystematic, Terry expressed doubts of LAMP's sincerity to award land titles. She related that she learned that LAMP is now moving to another municipality for titling services. "Why should they move when we do not have the titles yet? Is LAMP really sincere in its goal of helping land claimants get their titles?", Terry asked.

As regards cost incurred in her application, Terry noted that they have not spent much. She even said that their expenses have not reached $\$ 200$ yet. These expenses were on photocopying of some documents, tax declaration, and fare in going to and from Candahug to file some documents at the LAMP office.

Grace Posters is an heir to a 74-meter residential area where her house is located. At 56, Grace is still single. However, remaining single was really her plan. As her source of income, Grace operates a sari-sari store fronting her house. This store gives her an income of 2800 a week.

Like other residents in their barangay, Grace started processing her application in 2003 yet. Although she does not have title yet, Grace is so happy as she is sure that she will get it soon. She related that according to LAMP staff, her papers are already complete. "It's only a matter of time, my title will soon be released," she confided.

Grace is happy to report that her application did not cost her much. Based on receipts, her total expenses is 2111.88 only. These are for community tax certificate, tax declaration, and fare in going to the LAMP office in Candahug, Palo.

In general, Grace is satisfied with the services provided by LAMP. For one, since LAMP staff came to their barangay, it was no longer necessary for her to go to Tacloban. "Aside from freeing us from hassles, the service was advantageous as we did not have to spend for the fare. Add to that are the good attitude of the LAMP staff - accommodating and helpful." 


\section{IMPLICATIONS AND RECOMMENDATIONS}

Based on the data obtained from the illustrative cases, cost incurred to acquire land titles through the LAMP scheme is cheaper than the sporadic scheme. Deducing from the reports by respondents, the main factor for the disparity between the two schemes is the high amount incurred for fixers (especially in the case of judicial titles). Added to that are expenses on the agents whose promise to process land titles did not come to be.

Aside from the significant reduction on cost, the LAMP scheme has also shortened the land titling process. Data on the length of time respondents waited for their titles would prove this: in the LAMP scheme, titles were released within about a year or less but in the sporadic scheme, waiting time was about seven years.

These results clearly suggest the need for a sustained implementation of the LAMP scheme, especially in areas like the province of Leyte where most land claimants do not have titles yet. Needless to say most of these land claimants are farmers. As tenure security has implications to productivity, provision of titling services like that provided by LAMP would surely go a long way in attaining sustainability. Based on existing literature (e.g., Pulhin \& Dizon, 2000; Soriano, 2000; Wood \& Walker, 2001) efforts to attain sustainability may just prove futile if tenure of the land being cultivated is a problem.

Although the LAMP scheme may be advantageous, much remains to be desired. This can be deduced from the respondents' feedback on the services provided to them while they were still processing their land titles. In fact, they described the services as slow and difficult which could refer to both the staff attending their application and the entire titling scheme. In short, even if the LAMP scheme has significantly reduced the duration from application to release of the title, respondents still wish that the time be shortened further. 
Interestingly, one comment was that the procedure for land titling is not widely disseminated in their areas. This comment supports the claim that the procedure for titling is a difficult process. These two observations underscore one thing: that despite the production of communication materials on land titling, some claimants are not yet familiar with the procedure and the titing services and processes. While to some extent the communication materials may be producing the intended effects, it is suggested that production of land titling materials be rationalized and pursued within the framework of strategic communication campaigns. A strategic communication campaign could not only help improve land claimants knowledge of the services and procedures but also fill some information gaps more effectively (Adhikarya, 1994).

During the survey, respondents complained that they are not being updated by LAMP on the status of their title application. This situation has resulted in doubts on the part of the claimants. It is, therefore, suggested that updates on the status of title applications be released regularly. This update may be as simple as notices to be posted in the barangay bulletin boards.

\section{LITERATURE CITED}

ADHIKARYA, R. (1994). Strategic extension campaign: A participatoryoriented method of agricultural extension. Rome ltaly: Food and Agriculture Organization.

LAND ADMINISTRATION AND MANAGEMENT-PROJECT IMPLEMENTATION PROTOTYPE I (n.d.). Land titling implemented by LAMP (A Poster in the Waray-Waray dialect).

PROJECT MANAGEMENT OFFICE. 2002. Land Administration and Management Project. Available online. Retrieved on April 18, 2004 at http://www. phil-tamp.org/index.htm. 
PULHIN, J. M. \& DIZON, J. T. 2000. Politics of tenure reform in the Philippine forest. Available online. Retrieved on April 8, 2004 from:

http://dlc.dlib.indiana.edu/archive/00001108/00/Juan Pulhin\& Jo sefina Dizon-Philippines.pdf

SORIANO, M. 2000. Selective privatization of forestlands in the Philippines: An alternative approach to forest development. Available online. Retrieved on April 8, 2004 from http://dlc.dlib.indiana.edu/archive/00000355/00/sorianom042400. pdf

WOOD, C.H. \& WALKER, R. 2001. Land titles, tenure security and resource use among small farmers in the Brazilian Amazon. Retrieved on July 15,2004 from http://www.iussp.org/brzil2001/s60/s70 04 wood-pdf

\section{ABOUT THE AUTHORS}

Dr. Rotacio S. Gravoso finished his Ph.D. degree in Education (Learning Science and Curriculum Development) at Hiroshima University, Japan. Presently, he is a graduate faculty of the Department of Development Communication (DDC), and head of the Multi-media Development Center (MMDC), Visayas State University, Visca, Baybay, Leyte.

Mr. Ernesto F. Bulayog and Ms. Ma. Annabelle D. Gerona are Instructors of the Department of Economics and the Department of Development Communication, Visayas State University, Visca, Baybay, Leyte, respectively. 